\title{
Patterns of laccase and peroxidases in coarse woody debris of Fagus sylvatica, Picea abies and Pinus sylvestris and their relation to different wood parameters
}

\author{
Tobias Arnstadt ${ }^{1}\left(\mathbb{D} \cdot\right.$ Björn Hoppe $^{2,3} \cdot$ Tiemo Kahl $^{3} \cdot$ Harald Kellner $^{1}$ • \\ Dirk Krüger $^{2} \cdot$ Claus Bässler $^{4} \cdot$ Jürgen Bauhus $^{3} \cdot$ Martin Hofrichter $^{1}$
}

Received: 22 June 2015/Revised: 12 October 2015 / Accepted: 15 October 2015/Published online: 27 October 2015

(C) The Author(s) 2015. This article is published with open access at Springerlink.com

\begin{abstract}
Lignin and its degradation, particularly in forest ecosystems, play a major role in the global carbon cycle. Filamentous fungi equipped with extracellular oxidoreductases (oxidative enzymes), i.e., laccase, manganese-dependent peroxidases and several other peroxidases, are the key players in the bioconversion of lignin. In particular, for coarse woody debris (CWD), this process is poorly understood and the activities of laccase and peroxidases have never been studied on a large field scale. We investigated the activities of these enzymes in 701 samples of Fagus sylvatica, Picea abies and Pinus sylvestris CWD across three regions in Germany and analyzed their dependence on $\mathrm{pH}$, water content, wood density, total lignin, organic extractives, metals, watersoluble lignin fragments and fungal species richness. Respective enzyme activities were present in $79 \%$ of all samples, and the activities were highly variable and more
\end{abstract}

Handling Editor: Dr. Martina Meincken.

Electronic supplementary material The online version of this article (doi:10.1007/s10342-015-0920-0) contains supplementary material, which is available to authorized users.

Tobias Arnstadt

tobias.arnstadt@tu-dresden.de; arnstadt@ut-arnstadt.de

1 Department of Bio- and Environmental Sciences, International Institute Zittau, Technische Universität Dresden, Zittau, Germany

2 Department of Soil Ecology, UFZ - Helmholtz Centre for Environmental Research, Halle (Saale), Germany

3 Chair of Silviculture, Faculty of Environment and Natural Resources, University of Freiburg, Freiburg im Breisgau, Germany

4 Bavarian Forest National Park, Freyunger Str. 2, 94481 Grafenau, Germany frequent in $F$. sylvatica than in coniferous wood. Logistic regressions and correlations between enzyme activities and the variables revealed that the fungal community structure and the amount of water-soluble lignin fragments are most important determinants, and that the prevalent acidic $\mathrm{pH}$ in CWD is suitable to facilitate laccase and manganese peroxidase activities. Concentrations of metals (manganese, copper, iron) were sufficient to ensure synthesis and functioning of relevant enzymes. Based on this large field study, we conclude that laccase and peroxidases in CWD are highly relevant for lignin degradation, but the variable pattern of their secretion is the result of a complex array of wood parameters and the fungal community structure, which could only partly be resolved.

Keywords Laccase $\cdot$ Manganese peroxidase $\cdot$ General peroxidase $\cdot$ Dead wood $\cdot$ Lignin $\cdot$ Wood rot

\section{Introduction}

The degradation of lignin is of fundamental importance for the global carbon cycle (Dixon et al. 1994; Lundell et al. 2014; Weedon et al. 2009), especially in dead wood that represents globally $5 \%$ of organic carbon in forest ecosystems (FAO 2010). Lignin represents a barrier in wood that protects cellulose and hemicelluloses from microbial degradation (Kirk 1984). Only specialized filamentous fungi of the phylum Basidiomycota and some Ascomycota can substantially degrade lignin (Dix and Webster 1994; Liers et al. 2006). Due to the high lignin content in wood (20-40\%; Fengel and Wegener 2003), this process is essential for the mineralization of dead wood and increases the accessibility of the carbohydrates for 
other organisms such as non-ligninolytic fungi, bacteria or arthropods (Stokland et al. 2012).

Ecophysiologically, saprotrophic wood-inhabiting fungi can be classified, as a result of different degradation strategies, by the type of rot they are causing: white rot, brown rot and soft rot (type I and II) (Hatakka and Hammel 2011). All of these fungi are able to utilize and mineralize cellulose and hemicelluloses by different hydrolytic enzymes. The types of rot differ mainly in the ability and strategy to overcome the lignin barrier as well as in the time shift between lignin and polysaccharide degradation (Hatakka and Hammel 2011; Schwarze 2007). Typical white-rot fungi (WRF) actively secrete a set of extracellular oxidative enzymes (oxidoreductases EC 1.xx.x.x), i.e., peroxidases (EC 1.11.1.x) and phenol oxidases of the laccase type (Lacc, EC 1.10.3.2) (Lundell et al. 2010). Fungal secretory peroxidases can be phylogenetically divided into three large groups: (1) high-redox potential class II peroxidases, i.e., manganese peroxidase (MnP, EC 1.11.1.13), lignin peroxidase (LiP, EC 1.11.1.14), versatile peroxidase (VP, EC 1.11.1.16) and low-redox potential generic peroxidase (GP, EC 1.11.1.7), (2) dye-decolorizing peroxidases (DyP, EC 1.11.1.19) and (3) unspecific peroxygenases (UPO, EC 1.11.2.1) (Hofrichter 2002; Hofrichter and Ullrich 2014; Hofrichter et al. 2010). Among these peroxidases, only MnP, LiP and VP were shown to disintegrate polymeric lignin, while DyP and UPO have merely been demonstrated to cleave non-phenolic $\beta$-O-4-lignin model dimers (Hofrichter et al. 2010), and GP-type enzymes, on contrary, are rather involved in the polymerization of lignin (Kjalke et al. 1992). Equipped with varying sets of these oxidative enzymes, WRF reduce the lignin content of dead wood remarkably (Schwarze 2007).

In contrast, brown-rot fungi (BRF) do not secrete peroxidases, but they are applying a special radical mechanism with hydroxyl radicals (HO-) as oxidant, produced by the non-enzymatic Fenton reaction. Thus, BRF are not able to mineralize lignin to carbon dioxide $\left(\mathrm{CO}_{2}\right)$ as WRF do, and lignin is only modified, while the polymeric structure is kept intact (Hatakka and Hammel 2011). But BRF can efficiently attack hemicelluloses and cellulose, which leads to a relative increase in lignin frequently found in soft wood, since BRF prefer conifers (Hatakka and Hammel 2011; Ryvarden and Gilbertson 1993; Schwarze 2007).

Among the soft-rot fungi (SRF), Lacc is the most frequently found oxidative enzyme. These fungi (often filamentous ascomycetes, e.g., of the order Xylariales) mineralize lignin only to some extent, while cellulose and hemicelluloses are substantially degraded (Hatakka and Hammel 2011; Liers et al. 2006; Stokland et al. 2012).

Although lignin is widespread across different ecosystems, fungal degradation of wood and the involved enzymes has mainly been studied under artificial conditions in the laboratory. Experiments with pure fungal cultures on sterilized wood blocks and chips showed that each fungus provokes a unique temporal pattern of Lacc and peroxidase activities and that each of these enzymes contribute to a specific molecular mass distribution of watersoluble lignin fragments during degradation (Fackler et al. 2006; Hofrichter et al. 2001; Liers et al. 2011). Other laboratory experiments revealed the dependence of laccase and peroxidase production and their catalytic functioning on $\mathrm{pH}$ (e.g., acidic optimum of Lacc and MnP; Baldrian 2006; Hofrichter et al. 2010; Kirk and Cullen 1998) and specific metals. Thus, copper $\left(\mathrm{Cu}^{2+}\right)$ is part of the catalytic center of Lacc and induces its production (Baldrian 2006; Levin et al. 2005), iron $\left(\mathrm{Fe}^{3+}\right)$ is the central ion of protoporphyrin IX (heme) in the active site of most peroxidases including MnP, LiP and VP (Hofrichter et al. 2010), and manganese $\left(\mathrm{Mn}^{2+}\right)$ stimulates the production of $\mathrm{MnP}$ and is essential for the catalytic cycle of this enzyme (Brown et al. 1990; Hofrichter 2002).

In contrast to these detailed studies in the laboratory, the degradation of dead wood and the role of Lacc and peroxidases in the field have only scarcely been investigated with the exception of three recent studies. Valaskova et al. (2009) reported mean activities of Lacc and MnP from seven wood samples of different tree species, and van der Wal et al. (2015) mentioned activities of Lacc in 46 tree stumps of Quercus robur. Větrovský et al. (2010) determined Lacc and $\mathrm{MnP}$ activities in $F$. sylvatica and $B$. pendula samples (15 each) and found a significant level of spatial heterogeneity of these enzyme activities in decaying wood. However, our understanding of the factors that contribute to the considerable variability of Lacc and peroxidase activities in CDW is still limited.

In other field studies regarding dead wood decomposition, the actual decay activity of the whole decomposing community in CWD was assessed by respiration measurements, mass loss over time, decomposition rates, changes in the wood density or by the lignin content often along with molecular data (Boddy et al. 1989; Fukasawa et al. 2009a; Herrmann and Bauhus 2013; Rajala et al. 2012). However, to our best knowledge, no study has dealt with oxidative enzyme activities in CWD using a high sample number at a large spatial scale or analyzed their dependence on diverse predictors.

Therefore, we analyzed here Lacc and peroxidase activities in naturally occurring CWD of $F$. sylvatica, $P$. abies and $P$. sylvestris in temperate forest ecosystems within three regions across Germany. Based on laboratory studies, we hypothesize (H1) that these enzyme activities in CWD are promoted by acidic $\mathrm{pH}$ and positively correlated with the concentrations of $\mathrm{Mn}, \mathrm{Fe}$ and $\mathrm{Cu}$ as well as with water-soluble lignin fragments. Moreover, we expect a 
positive correlation of Lacc and peroxidase activities with the water content of CWD and a negative correlation with wood density, since similar results were reported for respirations rates, which are partly the result of lignin degradation (Hagemann et al. 2010; Herrmann and Bauhus 2013; Hofrichter et al. 1999). Fukasawa et al. (2009a) and Rajala et al. (2012) demonstrated a distinct fungal community development during deadwood degradation, and the composition of the fungal community was found to be the best predictor for mass loss in older stumps of $Q$. robur (van der Wal et al. 2015). In this context, we hypothesize (H2) that these fungal community changes will trigger the activities of Lacc and peroxidases. Finally, we assume a direct response of enzyme activities to the content of total lignin.

\section{Materials and methods}

\section{Study site}

This study was conducted in the context of the Biodiversity Exploratories (www.biodiversity-exploratories.de), (Fischer et al. 2010), a long-term and large-scale experiment for functional biodiversity research in Germany. The studied forests are located in the following three regions: (1) UNESCO Biosphere Reserve Schorfheide-Chorin (3-140 $\mathrm{m}$ a.s.l.) in the glacially formed lowland in northeastern part of Germany, (2) National Park Hainich-Dün and its surrounding areas (285-550 $\mathrm{m}$ a.s.1.) in the hilly lands of central Germany and (3) UNESCO Biosphere Reserve Schwäbische Alb and adjacent areas (460-860 m a.s.l.) in the low mountain range of southwestern Germany. The annual mean temperatures are in the range of $8-8.5$, $6.5-8$ and $6-7{ }^{\circ} \mathrm{C}$, and the annual mean precipitation varies between $500-600, \quad 500-800$ and $700-1000 \mathrm{~mm}$ for Schorfheide-Chorin, Hainich-Dün and Swabian Alb, respectively (Fischer et al. 2010).

Thirty plots (each $100 \times 100 \mathrm{~m}$, nine in SchorfheideChorin, nine in Schwäbische Alb, 12 in Hainich-Dün) of different forest management types were investigated. More detailed information about all forests plots is given in Fischer et al. (2010), Hessenmöller et al. (2011) and Luyssaert et al. (2011).

\section{Sample collection}

In April 2009, autochthonous, downed CWD was sampled within the plots. To cover a great spectrum of CWD, on each plot, slightly, moderately and strongly decayed logs were selected in the diameter classes $7-20 \mathrm{~cm}$ and $>20 \mathrm{~cm}$ for $F$. sylvatica and the dominant coniferous tree species ( $P$. abies or $P$. sylvestris). Due to limited availability of naturally occurring logs, not all diameter classes and decay stages could be covered for each species per plot. In total, $190 \operatorname{logs}$ were selected in the three explanatories (Table 1), of which $30 \%$ were slightly, $40 \%$ moderately and $30 \%$ strongly decayed (Online Resource: Table S1). The size classes were nearly equally represented for $F$. sylvatica and $P$. abies. Only for $P$. sylvestris, the size class $7-20 \mathrm{~cm}$ was overrepresented with $78 \%$ (Online Resource: Table S2).

From May to June 2009, dead wood samples were collected in the form of chips by drilling samples from the selected logs. A cordless Makita BDF451 (Makita, Anjo, Japan) equipped with a 42-cm-long wood auger with $2 \mathrm{~cm}$ diameter was used. From each log less than five meter long, three samples were taken. From logs longer than five meter, a further sample for every additional 5 meter was taken. The sampling positions were equally spaced over the whole length of the log, and the drill was introduced at an angle around $45^{\circ}$ to a vertical line perpendicular to the long axis. Depending on the log diameter at the sampling point, the auger was either drilled trough or inserted into its maximum length. Between the different samplings, the auger was flamed and wiped with ethanol to sterilize it. To avoid overheating, the drill operated slowly and the procedure was paused periodically. If drilling was not possible, due to fragile wood, a representative piece of wood was cut using a handsaw. In total, 399, 210 and 92 samples were taken from $F$. sylvatica, $P$. abies and $P$. sylvestris, respectively. The samples were kept on dry ice and later weighted and divided into three subsamples: (1) stored at $-18{ }^{\circ} \mathrm{C}$ for enzymatic studies, (2) stored at $-80{ }^{\circ} \mathrm{C}$ for F-ARISAs and (3) directly dried at $65{ }^{\circ} \mathrm{C}$ until constant mass for determination of the density and water content (Hoppe et al. 2014).

\section{Sample preparation}

Frozen samples $\left(-18{ }^{\circ} \mathrm{C}\right)$ were ground by an ultra-centrifugal mill $(<1 \mathrm{~min}, 10,000 \mathrm{rpm}, \mathrm{ZM}$ 1000, Retsch $\mathrm{GmbH}$, Haan, Germany) with a fixed ring sieve (1 mm mesh) and cooled by dry ice and liquid nitrogen.

Afterward, the samples were extracted with distilled water in a round-bottomed flask by vigorous shaking on a rotary shaker at $120 \mathrm{rpm}$ for $2 \mathrm{~h}$ at a temperature of $11^{\circ} \mathrm{C}$. The volume of distilled water was adjusted to the actual dry mass of samples using a ratio of $10 \mathrm{ml}$ for $1 \mathrm{~g}$. Extracts were filtered through a glass fiber filter (VWR, particle retention: $1.6 \mu \mathrm{m})$. Aqueous extracts were centrifuged $\left(10{ }^{\circ} \mathrm{C}, 10 \mathrm{~min}, 16,100 \times g\right)$, and the supernatants analyzed for activities of Lacc and peroxidases, $\mathrm{pH}$, bioavailable metals and the molecular mass distribution of water-soluble lignin fragments. Retained extracted wood samples were dried at $60{ }^{\circ} \mathrm{C}$ to a constant mass and used to determine organic extractives and Klason lignin. 
Table 1 Parameters of studied coarse woody debris

\begin{tabular}{llll}
\hline & Fagus sylvatica & Picea abies & Pinus sylvestris \\
\hline Number of logs & 112 & 55 & 23 \\
In Schorfheide-Chorin & 28 & 0 & 23 \\
In Hainich-Dün & 46 & 19 & 0 \\
In Schwäbische Alb & 38 & 36 & 0 \\
Number of samples & 399 & 210 & 92 \\
Log diameter $(\mathrm{cm})^{\text {a }}$ & $26 \pm 19(6-90)$ & $24 \pm 12(10-70)$ & $19 \pm 10(10-51)$ \\
Log length $(\mathrm{m})^{\mathrm{a}}$ & $8 \pm 6(2-33)$ & $9 \pm 6(2-31)$ & $10 \pm 6(3-24)$ \\
\hline
\end{tabular}

${ }^{a}$ Mean values \pm standard deviation, and in brackets, the ranges (min and max) are given

\section{Activities of Lacc and peroxidases}

Activities were photometrically measured in the aqueous extracts in 96-well plates (F-bottom, Greiner Bio-One $\mathrm{GmbH}$, Frickenhausen, Germany) with a plate reader (Infinite M200, Tecan, Männedorf, Switzerland) by following the oxidation of ABTS (2,2'-azino-bis(3-ethylbenzothiazoline-6-sulfonic acid), $\varepsilon_{420}=36.0 \mathrm{~cm}^{-1} \mathrm{mM}^{-1}$ ). After mixing $50 \mu \mathrm{l}$ sample extract and $195 \mu \mathrm{l}$ ABTS buffer solution, the assay contained $0.3 \mathrm{mM}$ ABTS and $50 \mathrm{mM}$ sodium malonate buffer ( $\mathrm{pH} 4.5$ ) (Hahn et al. 2013; Liers et al. 2011). At first, Lacc activity was measured over 5 min immediately after addition of the sample extract under two different conditions in order to differentiate the subsequent peroxidase assays: (1) in sodium malonate buffer additionally containing ethylenediaminetetraacetic acid (EDTA, Titriplex III, $0.5 \mathrm{mM}$ ) for complexing naturally occurring free metal ions (in first place $\mathrm{Mn}^{2+}$; Větrovský et al. 2010) and (2) in sodium malonate buffer with $\mathrm{Mn}^{2+}\left(\mathrm{MnCl}_{2}, 0.5 \mathrm{mM}\right)$ and without EDTA. General peroxidase (GenP) activity was measured by following the increase in absorption at $420 \mathrm{~nm}$ after addition of hydrogen peroxide $\left(\mathrm{H}_{2} \mathrm{O}_{2}, 0.1 \mathrm{mM}\right)$ in the EDTA-containing assay solution for $5 \mathrm{~min}$. GenP activity was corrected by subtraction of the determined Lacc activity. In parallel, manganese-dependent peroxidase (MnP) activity was measured in the assay solution with $\mathrm{Mn}^{2+}$ after addition of $0.1 \mathrm{mM}$ $\mathrm{H}_{2} \mathrm{O}_{2}$ over 5 min. MnP activity was finally calculated by subtraction of Lacc (with $\mathrm{Mn}^{2+}$ ) and GenP activities. The GenP activity stands for the sum activity of a genetically diverse set of fungal peroxidases that can include LiP, VP, GP, UPO and DyP in the absence of $\mathrm{Mn}^{2+}$, which is why the GenP activity has also been described as activity of manganese-independent peroxidases (MiP; Kellner et al. 2014). All measurements were taken in duplicate and were repeated when the absorbance increase in the two measurements was strongly deviating. For further analyses, the mean values were used. All enzymatic activities are given in international units $(\mathrm{U} ; 1 \mathrm{U}=1000 \mathrm{mU}=16.67 \times$ $10^{-9}$ kat) defined as the amount of enzyme that forms $1 \mu \mathrm{mol}$ of product per minute under the assay conditions used; they were related to the original dry mass of wood: $\mathrm{mU} \mathrm{g}^{-1}$.

\section{Physico-chemical properties of the wood samples}

To assess water-soluble lignin fragments, high-performance size exclusion chromatography (HPSEC) was used to determine their molecular mass distribution in the aqueous extracts (Hofrichter et al. 2001; Liers et al. 2011). The HPLC system (Agilent 1100 Liquid Chromatography; Agilent Technologies, Santa Clara, USA) was equipped with a diode array detector and fitted with a HEMA-Bio linear column $(8 \times 300 \mathrm{~mm}, 10 \mu \mathrm{m})$ from Polymer Standard Service (Mainz, Germany). The mobile phase consisted of $20 \%$ acetonitrile and $80 \%$ of aqueous buffer ( $\mathrm{pH} \mathrm{10;0.34 \%}$ $(\mathrm{m} / \mathrm{v}) \mathrm{NaCl}$ and $\left.0.2 \%(\mathrm{~m} / \mathrm{v}) \mathrm{K}_{2} \mathrm{HPO}_{4}\right)$. The following separation parameters were used: flow rate $1 \mathrm{ml} \mathrm{min}^{-1}$, detection wavelength $280 \mathrm{~nm}$ and injection volume $50 \mu \mathrm{l}$. Sodium polystyrene sulfonates (0.8-1010 kDa, Polymer Standard Service, Mainz, Germany) served as molecular mass standards. The amount of water-soluble lignin fragments was derived from the peak area under the elution profile calibrated with a chlorolignin standard (Lackner et al. 1991; Soares and Duran 2001).

Bioavailable metals (copper, manganese and iron) in CWD were determined in the aqueous extracts using inductively coupled plasma (ICP) optical emission spectrometry (ICP-OES) and mass spectrometry (ICP-MS) according to manufacturers' specifications. The ICP-OES device Optima 3000 (PerkinElmer Inc., Waltham, MA, USA) was calibrated using the ICP multi-element standard solution IV ( $\mathrm{Mn}, \mathrm{Fe}, \mathrm{Cu}$; Merck, Darmstadt, Germany) from 0 to $10 \mathrm{mg} \mathrm{l}^{-1}$. The ICP-MS Elan DRC-e (PerkinElmer) device was calibrated using ICP multi-element standard solution VI (Mn, Fe, Cu; Merck) in 2, 15, 50 and $500 \mu \mathrm{g}^{-1}$ (only Fe) concentrations.

The content of lignin and organic extractives of the solid wood samples was determined after aqueous extraction and drying $\left(\right.$ at $\left.60{ }^{\circ} \mathrm{C}\right)$. Each sample was extracted by accelerated solvent extraction (Dionex ASE 200) with acetone (cell size: $5 \mathrm{ml}$; preheating: $1 \mathrm{~min}$; static equilibration 
period: $100{ }^{\circ} \mathrm{C}$, 1500 PSI, $3 \times 5 \mathrm{~min}$; flush: $80 \%$; purge: $300 \mathrm{~s}$ ). From the resulting extract, acetone was evaporated at $60{ }^{\circ} \mathrm{C}$ under nitrogen flush. The remaining residues were dried at $120^{\circ} \mathrm{C}$ over night and weighted. The content of organic extractives was expressed per gram of original dry mass of wood (Liers et al. 2011).

The extracted samples were ground by a planetary ball mill (5 min, $650 \mathrm{rpm}$, Pulverisette 7, Retsch, Idar-Oberstein, Germany) to a fine powder. Klason lignin content was measured gravimetrically as dry weight of solids after sequential hydrolysis with sulfuric acid $(72 \%(\mathrm{v} / \mathrm{v})$ at $30{ }^{\circ} \mathrm{C}$ for $1 \mathrm{~h}$ and $2.4 \%(\mathrm{v} / \mathrm{v})$ at $120{ }^{\circ} \mathrm{C}$ for $1 \mathrm{~h}$; Effland 1977). Acid-soluble lignin was measured photometrically according to Dence (1992). The UV absorbance of the hydrolysate containing acid-soluble lignin was recorded at $205 \mathrm{~nm}\left(\varepsilon=110 \mathrm{~g}^{-1} \mathrm{~cm}^{-1}\right)$. The Klason lignin and acidsoluble lignin contents were expressed per gram of original dry mass of wood.

Wood density was calculated from the dry weight $\left(65^{\circ} \mathrm{C}\right.$ ) divided by the sample volume (volume of the drilled hole). Water content is expressed as mass of water per unit of dry mass of wood.

\section{Fungal community in the wood samples}

The total community DNA from $1 \mathrm{~g}$ wood powder of each sample was isolated using a modified CTAB protocol (Doyle and Doyle 1987). Nine hundred microliters of CTAB was added to the sample, and the nucleic acids were separated from proteins and cell debris by adding $500 \mu \mathrm{l}$ of 24:1 chloroform:isoamyl alkohol (Carl Roth, Karlsruhe, Germany) followed by another chloroform step (Carl Roth, Karlsruhe, Germany). DNA was precipitated by washing the sample twice with ethanol (Merck, Darmstadt, Germany). Dried pellets were eluted in $100 \mu \mathrm{l}$ molecular water (AppliChem, Darmstadt, Germany).

F-ARISA PCR (fungal automated ribosomal intergenic spacer analysis PCR; Ranjard et al. 2001; Purahong et al. 2014) of each DNA extract was done in two replicates using a FAM-labeled primer ITS1-F (5'-CTTGGTCATT TAGAGGAAGTAA-3', Gardes and Bruns 1993) and unlabeled ITS4 (5'-TCCTCCGCTTATTGATATGC-3', White et al. 1990) in $30 \mu \mathrm{l}$ reaction mixtures containing $6 \mu$ FIREPol 5× Master Mix (Solis BioDyne, Tartu, Estonia), $15 \mu \mathrm{M}$ of each Primer and $1 \mu \mathrm{l}$ template DNA. PCR was performed with an initial denaturation step at $95^{\circ} \mathrm{C}$ for 5 min followed by 35 cycles at $95{ }^{\circ} \mathrm{C}$ for $60 \mathrm{~s}$, $55^{\circ} \mathrm{C}$ for $60 \mathrm{~s}$ and $72{ }^{\circ} \mathrm{C}$ for $75 \mathrm{~s}$. Elongation was completed with a final step at $72{ }^{\circ} \mathrm{C}$ for $7 \mathrm{~min}$.

PCR products were purified using the E.Z.N.A. ${ }^{\circledR}$ CyclePure Kit (Omega Bio-Tek, Inc., Norcross, GA, USA). $10 \mathrm{ng}$ of each purified PCR product was dissolved in $14 \mu \mathrm{l}$ of deionized Hi-Di formamide (Applied Biosystems, Foster
City, CA) with $0.1 \mu \mathrm{l}$ of internal size standard Map Marker 1000 ROX (BioVentures, Inc., Murfreesboro, TN, USA). After denaturation for $5 \mathrm{~min}$ at $95^{\circ} \mathrm{C}$, samples were chilled on ice for at least $10 \mathrm{~min}$. Length heterogeneity of fungal ITS fragments (approximately 450-1000 bp) was detected by capillary electrophoresis (ABI 3730xl, Applied Biosystems). Electrophoretic conditions were as follows: seven-second-injection at $1.6 \mathrm{kV}$ and separation at $15 \mathrm{kV}$ for $3800 \mathrm{~s}$. Row profiles were analyzed using Gene Mapper software 4.0 (Applied Biosystems). All peaks above a threshold of 100 fluorescence units, which were present in both technical replicates, were considered for further analyses. OTU binning was performed with the interactive and automatic R binning script (Ramette 2009) using R (R Core Team 2014). According to the script and its correlation values, a window size of two was chosen.

\section{Statistics}

All statistical analyses were performed in R 3.0.3 (R Core Team 2014). The data were tested for normal distribution applying the Shapiro-Wilk normality test. Differences between tree species were tested by the Kruskal-Wallis test for significance $(p<0.05)$ that was followed by a paired Mann-Whitney test with Bonferroni correction.

Separately for each tree species, the influence of all physico-chemical properties, species richness and fungal community (independent variables) on the activity of Lacc, GenP and MnP was analyzed by fitting multiple linear and generalized linear mixed-effect models with region, plot and CWD log as nested random effects. At first, the fungal community matrix was arcsin transformed and ordinated with NMDS applying the function "metaMDS" in vegan package (2.0-10; Oksanen et al. 2013). The first two axes (Online Resource: Fig. S1) were extracted and used as proxy for the fungal community in the multiple models. Before modeling, the normal distribution of all independent variables was checked and, if necessary, transformed (Online Resource: Table S3). To avoid highly correlated independent variables in the models, the co-correlation of the transformed independent variables was checked by correlation analysis (Online Resource: Table S4-S6). Since water content and wood density were highly correlated as well as water-soluble lignin fragments, copper, iron and manganese showed high correlation, only the water content and water-soluble lignin fragments were used in the multiple models, and the others were excluded.

Since $21 \%$ of all samples did not contain any of the analyzed enzyme activities $\left(<1 \mathrm{mU} \mathrm{g}^{-1}\right.$, Table 2$)$, the influence of the independent variables on the probability to detect Lacc, GenP or MnP was analyzed by logistic regression. For this analysis, the enzyme data were converted into presence $\left(\geq 1 \mathrm{mU} \mathrm{g}^{-1}\right)$ or absence 
Table 2 Percentage of CWD samples with different combinations of Lacc and peroxidases $\geq 1 \mathrm{mU} \mathrm{g}^{-1}$

\begin{tabular}{llllll}
\hline Lacc $^{\mathrm{a}}$ & GenP $^{\mathrm{a}}$ & $\mathrm{MnP}^{\mathrm{a}}$ & F. sylvatica (\%) & P. abies (\%) & P. sylvestris (\%) \\
\hline- & - & - & 9 & 35 & 40 \\
+ & - & - & 13 & 18 & 14 \\
- & + & 4 & 4 & 3 \\
- & + & 1 & 1 & 3 \\
+ & - & 12 & 7 & 11 \\
+ & + & 15 & 6 & 9 \\
- & - & + & 5 & 3 & 1 \\
+ & + & + & 26 & 18 \\
Samples containing Lacc & & 63 & 57 & 52 \\
Samples containing GenP & & 63 & 40 & 34 \\
Samples containing MnP & & 91 & 36 & 32 \\
Samples containing any oxidoreductase & & 65 & 60
\end{tabular}

${ }^{a}$ Combinations are with $(+)$ and without $(-)$ the corresponding enzyme activities $\left(<1 \mathrm{mU} \mathrm{g}^{-1}\right)$ of the corresponding enzyme activities per analyzed sample. Logistic regressions were modeled as generalized linear mixed model using the Lme4 package (1.0-6; Bates et al. 2014) with region, plot and CWD log as nested random effects, and the independent variables were $z$-scaled. Before fitting the multiple logistic models, a univariate linear and quadratic logistic model was fitted for each enzyme type in dependence of each independent variable. They were plotted together with the mean probability and standard deviation from eight intervals across the range of the independent variable to evaluate graphically the need of a quadratic term according to Crawley (2012). Further significance $(p<0.05)$ of the quadratic term was tested by an analysis of variance (ANOVA) comparing the linear and quadratic model.

In a second step, we analyzed the dependence of present enzyme activities on the independent variables. To exclusively analyze samples where the enzyme type of interest is present, the data set was reduced to samples containing the corresponding enzyme with activities of $\geq 1 \mathrm{mU} \mathrm{g}^{-1}$. The enzyme activities were checked for normal distribution and transformed to better fit to a normal distribution (Online Resource: Table S7). Before fitting the multiple linear models, the enzyme activities were plotted in dependence of the independent parameters to explore the relevance of quadratic terms. The multiple linear mixed-effects models were fitted with the function "lme" from the "nlme" package (Pinheiro et al. 2013) with region, plot and CWD log as nested random effects. Therefore, the enzyme activities and the independent parameters were $z$-scaled.

Best model selection was conducted for logistic regression and linear regressions by the $R$ function "dredge" from the $R$ package "MuMIn" (Bartoń 2015), an automated full information criteria-based model selection approach, evaluated on the basis of Bayesian information criteria (BIC). To estimate the explanatory power of the final models, "Nakagawa \& Schielzeth's minor $r$-square" (Nakagawa and Schielzeth 2013) was calculated using the $R$ function " $r$.squared" supplied by Lefcheck (2014).

\section{Results}

\section{Enzyme activities in wood samples}

One of the three types of oxidoreductase activities (Lacc, GenP and MnP) was found in 91, 65 and $60 \%$ of all samples of $F$. sylvatica, $P$. abies and $P$. sylvestris, respectively. Combinations of these enzyme activities were observed in 42, 26 and $18 \%$ of all the wood samples in regard to tree species (Table 2). Vice versa, no oxidoreductase activity was detected in 9,35 and $40 \%$ of $F$. sylvatica, $P$. abies and $P$. sylvestris samples, respectively. In general, a wide range of enzyme activities from 0 up to 1209, 333 and $929 \mathrm{mU} \mathrm{g}^{-1}$ were measured for Lacc, GenP and $\mathrm{MnP}$, respectively (Table 3 ). All maximum enzyme activities were found in $F$. sylvatica CWD. The majority of samples showed enzyme activities lower than $10 \mathrm{mU} \mathrm{g}^{-1}$. In general, a high variability of enzymatic activities was observed within individual logs. The mean of all coefficients of variation in each individual log ranged from 118 to $155 \%$ for each enzyme and each tree species (Table 3 ).

Significant $(p<0.01)$ higher activities of Lacc, GenP and $\mathrm{MnP}$ were found in wood of $F$. sylvatica than in coniferous wood (Table 3). In all CWD tree species, peroxidases showed significantly $(p<0.01)$ lower activities than Lacc and were detected in a smaller percentage of samples (Table 2). However, the percentage of samples with GenP or MnP activities was similar. The activities of 
Table 3 Summary statistics of measured Lacc and peroxidase activities

\begin{tabular}{|c|c|c|c|c|c|c|c|c|c|}
\hline \multirow[t]{2}{*}{ CWD type } & \multicolumn{7}{|c|}{ Enzyme activity $\left(\mathrm{mU} \mathrm{g}^{-1}\right)$} & \multirow{2}{*}{$\begin{array}{l}\text { Mean SD in CWD } \\
\operatorname{logs}\left(\mathrm{mU} \mathrm{g}^{-1}\right)\end{array}$} & \multirow{2}{*}{$\begin{array}{l}\text { Mean CV in } \\
\text { CWD logs }(\%)\end{array}$} \\
\hline & Min & $\mathrm{Q}_{25} \%$ & Median & $\mathrm{Q}_{75} \%$ & $\mathrm{Q}_{95 \%}$ & Max & & & \\
\hline \multicolumn{10}{|l|}{ Laccase } \\
\hline F. sylvatica & 0 & 2 & 12 & 57 & 341 & 1209 & $a^{a}$ & 78 & $118 \pm 44$ \\
\hline P. abies & 0 & 0 & 1 & 10 & 112 & 784 & $\mathrm{~b}$ & 33 & $148 \pm 42$ \\
\hline P. sylvestris & 0 & 0 & 1 & 5 & 62 & 287 & $\mathrm{~b}$ & 15 & $129 \pm 51$ \\
\hline \multicolumn{10}{|c|}{ General peroxidase } \\
\hline F. sylvatica & 0 & 0 & 2 & 11 & 73 & 333 & a & 17 & $125 \pm 46$ \\
\hline P. abies & 0 & 0 & 0 & 3 & 32 & 306 & $\mathrm{~b}$ & 9 & $154 \pm 52$ \\
\hline P. sylvestris & 0 & 0 & 0 & 1 & 8 & 24 & $\mathrm{~b}$ & 2 & $140 \pm 66$ \\
\hline \multicolumn{10}{|c|}{ Manganese peroxidase } \\
\hline F. sylvatica & 0 & 0 & 2 & 16 & 102 & 929 & $\mathrm{a}$ & 30 & $131 \pm 45$ \\
\hline P. abies & 0 & 0 & 0 & 2 & 51 & 375 & $\mathrm{~b}$ & 14 & $155 \pm 50$ \\
\hline P. sylvestris & 0 & 0 & 0 & 1 & 3 & 9 & $\mathrm{~b}$ & 1 & $155 \pm 56$ \\
\hline
\end{tabular}

The minimum, the $25 \%, 50 \%$ (median), $75 \%$ and $95 \%$ quantiles and maximum of the different enzyme activities in samples from $F$. sylvatica, $P$. abies and $P$. sylvestris are given. Standard deviation (SD) and coefficient of variation (CV) within each individual log were calculated and given as mean SD and CV over all logs

${ }^{\mathrm{a}}$ Different letters $(\mathrm{a}, \mathrm{b})$ indicate statistically significant differences between tree species for the corresponding enzyme activities at $p<0.05$

all these enzymes showed a strong positively skewed distribution.

\section{Physico-chemical properties and fungal species richness of CWD samples}

Most physico-chemical properties showed significant differences between $F$. sylvatica CWD and coniferous wood (Table 4). The $\mathrm{pH}$ values were in the range from 3.0 to 7.5 and had a significant lower median in coniferous wood $(\mathrm{pH}$ 4.4) than in F. sylvatica (pH 5.1).

The amount of water-soluble lignin fragments varied between 0.2 and $99.4 \mathrm{mg} \mathrm{g}^{-1}$ and showed a significant lower median in coniferous wood $\left(6.8 \mathrm{mg} \mathrm{g}^{-1}\right)$ compared to wood of $F$. sylvatica $\left(9 \mathrm{mg} \mathrm{g}^{-1}\right)$. The main fraction of water-soluble lignin fragments had a molecular mass around $1 \mathrm{kDa}$ (Fig. 1). This fraction was found in 74, 65 and $69 \%$ of all samples in $F$. sylvatica, $P$. abies and $P$. sylvestris, respectively. The second smaller peak representing a fraction around $40 \mathrm{kDa}$ was present in 49,10 and $11 \%$ of all samples in $F$. sylvatica, $P$. abies and $P$. sylvestris, respectively.

Water-soluble (i.e., bioavailable) manganese, copper and iron had median concentrations of 14.2, 0.35 and

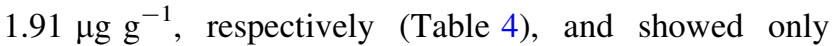
slight differences between the tree species. Among each other and with water-soluble lignin fragments, they showed strong correlations (Online Resource: Table S4-S6). The corresponding median metal concentrations in the aqueous phase of CDW (deduced from the water content of CDW) were 206, 4 and $30 \mu \mathrm{M}$ for manganese, copper and iron, respectively (Online Resource: Table S8).
The median contents of total lignin and wood extractives in coniferous wood were significantly higher than in $F$. sylvatica (Table 4). CWD density increased from $P$. abies over $P$. sylvestris to $F$. sylvatica with a median of 0.24 , 0.29 and $0.33 \mathrm{~g} \mathrm{~cm}^{-3}$, respectively. In contrast, the water content did not show significant differences between the tree species ranging from 0.3 to $11.3 \mathrm{~g} \mathrm{~g}^{-1}$ (Table 4). Water content and wood density were found to be strongly negatively correlated $(R$ : $-0.82,-0.79$ and -0.85 for $F$. sylvatice, $P$. abies and $P$. sylvestris, respectively).

The fungal species richness exhibited significantly higher OTU numbers in coniferous CWD than in $F$. sylvatica CWD with medians of 15,19 and 21 OTUs for $F$. sylvatica, $P$. abies and $P$. sylvestris, respectively (Table 4).

\section{Probability to detect Lacc, GenP and MnP activities}

Due to the high percentage of samples that did not show any activity of Lacc, GenP or MnP (Table 2), we modeled in a first step the probability to detect respective enzymatic activities $\left(\geq 1 \mathrm{mU} \mathrm{g}^{-1}\right)$ in dependence of the physicochemical properties, the first and second axis of the NMDS ordination for the fungal community and species richness as logistic regressions.

The final models for the probability to detect Lacc, GenP and MnP activities in $F$. sylvatica CWD showed only low minor $r$-squares (0.03-0.11), whereas for the models of coniferous CWD, the values were clearly higher (0.14-0.52; Table 5). The variable that contributed most frequently (five times) to the final models was the 
Table 4 Summary statistics of physico-chemical properties and species richness

\begin{tabular}{|c|c|c|c|c|c|c|c|}
\hline & CWD type & Min & $\mathrm{Q}_{25} \%$ & Median & $\mathrm{Q}_{75 \%}$ & $\operatorname{Max}$ & \\
\hline \multicolumn{8}{|l|}{$\mathrm{pH}$} \\
\hline & F. sylvatica & 3.4 & 4.7 & 5.1 & 5.7 & 7.4 & $\mathrm{a}^{\mathrm{a}}$ \\
\hline & P. abies & 3.0 & 4.0 & 4.4 & 4.9 & 7.5 & $\mathrm{~b}$ \\
\hline & P. sylvestris & 3.1 & 4.1 & 4.4 & 4.7 & 6.3 & $\mathrm{~b}$ \\
\hline \multicolumn{8}{|l|}{$c_{\mathrm{Mn}}\left(\mu \mathrm{g} \mathrm{g}^{-1}\right)$} \\
\hline & F. sylvatica & 0.1 & 5.4 & 13.0 & 31.1 & 361.3 & $\mathrm{a}$ \\
\hline & P. abies & 0.3 & 7.7 & 13.1 & 34.3 & 193.9 & $\mathrm{a}, \mathrm{b}$ \\
\hline & P. sylvestris & 2.4 & 9.3 & 20.9 & 32.3 & 106.6 & $\mathrm{~b}$ \\
\hline \multicolumn{8}{|l|}{$c_{\mathrm{Cu}}\left(\mu \mathrm{g} \mathrm{g}^{-1}\right)$} \\
\hline & F. sylvatica & 0.1 & 0.3 & 0.4 & 0.5 & 3.0 & $\mathrm{a}$ \\
\hline & P. abies & 0.0 & 0.2 & 0.3 & 0.5 & 2.2 & $\mathrm{~b}$ \\
\hline & P. sylvestris & 0.1 & 0.2 & 0.3 & 0.4 & 1.5 & $\mathrm{~b}$ \\
\hline \multicolumn{8}{|l|}{$c_{\mathrm{Fe}}\left(\mu \mathrm{g} \mathrm{g}^{-1}\right)$} \\
\hline & F. sylvatica & 0.1 & 1.1 & 1.9 & 3.3 & 44.8 & $\mathrm{a}$ \\
\hline & P. abies & 0.1 & 0.9 & 2.0 & 4.7 & 38.6 & $\mathrm{a}$ \\
\hline & P. sylvestris & 0.1 & 0.7 & 1.5 & 3.3 & 13.7 & $\mathrm{a}$ \\
\hline \multicolumn{8}{|l|}{$\begin{array}{l}\text { Amount of water-soluble } \\
\text { lignin fragments }\left(\mathrm{mg} \mathrm{g}^{-1}\right)\end{array}$} \\
\hline & F. sylvatica & 0.9 & 5.1 & 9.0 & 14.7 & 99.4 & $\mathrm{a}$ \\
\hline & P. abies & 0.2 & 3.4 & 6.8 & 11.5 & 48.4 & $\mathrm{~b}$ \\
\hline & P. sylvestris & 0.3 & 2.5 & 6.8 & 9.8 & 22.8 & $\mathrm{~b}$ \\
\hline \multicolumn{8}{|l|}{ Extractives (\%) } \\
\hline & F. sylvatica & 0.1 & 0.5 & 0.7 & 1.2 & 7.0 & $\mathrm{a}$ \\
\hline & P. abies & 0.2 & 1.1 & 1.8 & 2.8 & 13.1 & $\mathrm{~b}$ \\
\hline & P. sylvestris & 0.8 & 2.6 & 4.0 & 9.1 & 24.1 & $\mathrm{c}$ \\
\hline \multicolumn{8}{|l|}{ Total lignin (\%) } \\
\hline & F. sylvatica & 19 & 26 & 28 & 31 & 73 & $\mathrm{a}$ \\
\hline & P. abies & 23 & 30 & 32 & 41 & 90 & $\mathrm{~b}$ \\
\hline & P. sylvestris & 19 & 29 & 31 & 37 & 59 & $\mathrm{~b}$ \\
\hline \multicolumn{8}{|l|}{ Density $\left(\mathrm{g} \mathrm{cm}^{-3}\right)$} \\
\hline & F. sylvatica & 0.03 & 0.19 & 0.32 & 0.48 & 0.69 & $\mathrm{a}$ \\
\hline & P. abies & 0.02 & 0.16 & 0.24 & 0.33 & 0.48 & $\mathrm{~b}$ \\
\hline & P. sylvestris & 0.08 & 0.17 & 0.29 & 0.38 & 0.53 & $\mathrm{a}$ \\
\hline \multicolumn{8}{|l|}{ Water content $\left(\mathrm{g} \mathrm{g}^{-1}\right)$} \\
\hline & F. sylvatica & 0.30 & 0.69 & 1.25 & 2.42 & 11.27 & $\mathrm{a}$ \\
\hline & P. abies & 0.34 & 0.70 & 1.30 & 2.53 & 6.90 & $\mathrm{a}$ \\
\hline & P. sylvestris & 0.30 & 0.70 & 1.25 & 1.95 & 5.39 & $\mathrm{a}$ \\
\hline \multicolumn{8}{|l|}{ Species richness (OTUs) } \\
\hline & F. sylvatica & 1 & 8 & 15 & 23 & 57 & $\mathrm{a}$ \\
\hline & P. abies & 2 & 13 & 19 & 28 & 47 & $\mathrm{~b}$ \\
\hline & P. sylvestris & 6 & 15 & 21 & 25 & 45 & $\mathrm{~b}$ \\
\hline
\end{tabular}

The minimum, the $25 \%, 50 \%$ (median) and $75 \%$ quantiles and maximum of the different parameters in samples from $F$. sylvatica, P. abies and $P$. sylvestris are given

${ }^{a}$ Different letters $(\mathrm{a}, \mathrm{b}, \mathrm{c})$ indicate statistically significant differences between tree species for the corresponding parameter at $p<0.05$

community structure, which was represented by both NMDS axes. The amount of water-soluble lignin fragments and the $\mathrm{pH}$ contributed to four models, and they were followed by the wood extractives and the water content, which were part of three different models. In models considering water-soluble lignin fragments or the water 


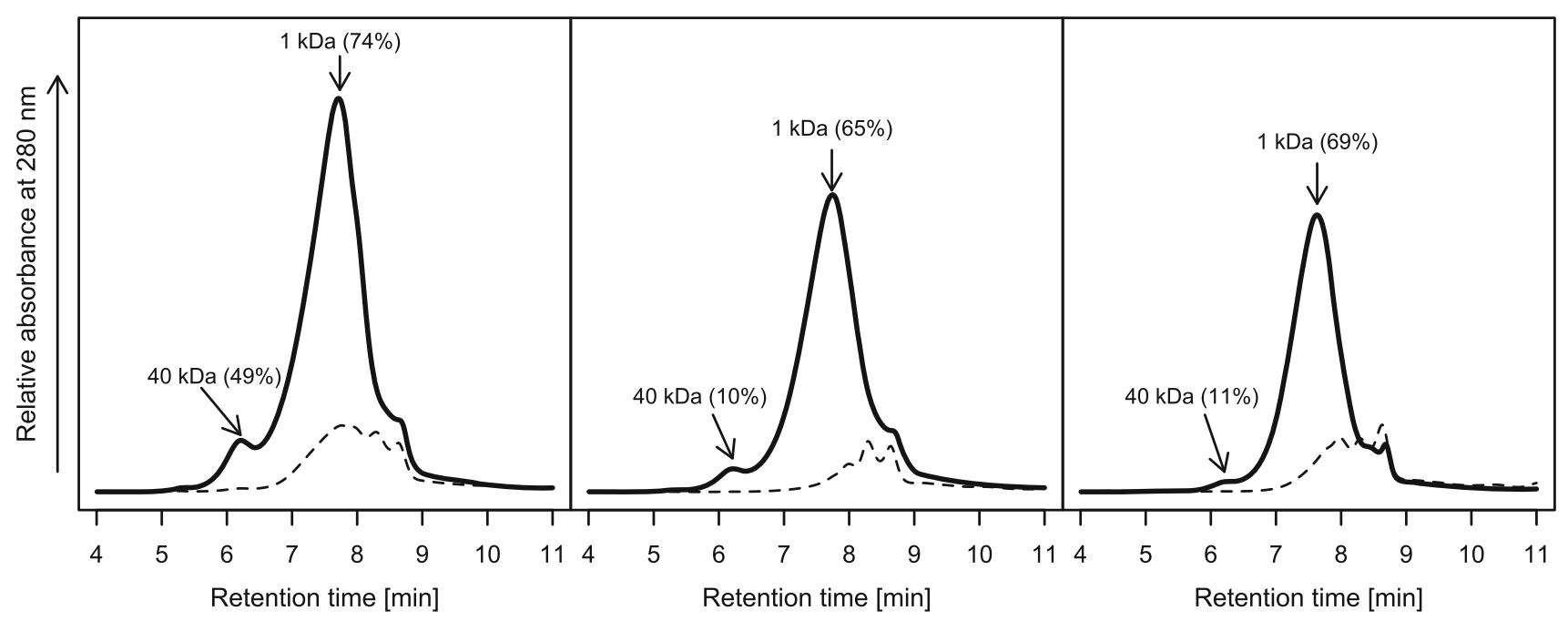

Fig. 1 Averaged chromatograms of water-soluble lignin fragments. The molecular mass distribution of lignin fragments in aqueous extracts of CWD samples (solid line) and sound wood (dashed line) of
$F$. sylvatica, $P$. abies and $P$. sylvestris is shown. Corresponding molecular masses of the peaks are marked with arrows, and the percentages of samples exhibiting these peaks are given in brackets

Table 5 Selected final models for logistic models predicting the probability to detect activities of Lacc, GenP and $\mathrm{MnP} \geq 1 \mathrm{mU} \mathrm{g}^{-1}$

\begin{tabular}{|c|c|c|c|c|c|c|c|c|c|}
\hline \multirow[t]{2}{*}{ Variable } & \multicolumn{3}{|c|}{ F. sylvatica } & \multicolumn{3}{|l|}{ P. abies } & \multicolumn{3}{|c|}{ P.sylvestris } \\
\hline & Lacc & GenP & $\mathrm{MnP}$ & Lacc & GenP & $\mathrm{MnP}$ & Lacc & GenP & $\mathrm{MnP}$ \\
\hline Intercept & $2.70 * * *$ & $0.60 * * *$ & $0.56 * * *$ & $0.49 * *$ & $-0.51 * *$ & $-0.44 *$ & $0.22^{\mathrm{NS}}$ & $-0.44^{\mathrm{NS}}$ & $-0.97 * *$ \\
\hline $\mathrm{pH}$ & & & & $0.93^{* * *}$ & & $-0.36^{* *, \mathrm{a}}$ & & $-0.53^{+, \mathrm{a}}$ & $1.03 * *$ \\
\hline \multicolumn{10}{|l|}{ Total lignin } \\
\hline Extractives & & & & $-0.66^{* *}$ & $-0.58 * *$ & $-0.75^{* * *}$ & & & \\
\hline Water-soluble lignin fragments & $0.81 * * *$ & & & $1.20 * * *$ & & $0.82 * * *$ & & & $1.05 * *$ \\
\hline Water content & & $0.47 * * *$ & & & $0.74 * * *$ & & & $0.75^{*}$ & \\
\hline Species richness & $0.50 *$ & & & & & & & & \\
\hline NMDS axis 1 & & & $0.30 * *$ & & & & $-0.88 * *$ & & \\
\hline NMDS axis 2 & & & & $-1.01 * * *$ & $-0.45 * *$ & $-0.59 * * *$ & & & \\
\hline Minor $r$-square & 0.11 & 0.06 & 0.03 & 0.52 & 0.21 & 0.36 & 0.14 & 0.30 & 0.18 \\
\hline
\end{tabular}

The estimated parameters and their significance of each variable, which is retained in the final model, are given together with the minor $R^{2}$ of the whole final model

Significance of the estimated parameters in the model is symbolized by: ${ }^{\mathrm{NS}} p \geq 0.1 ; \quad+0.05 \leq p<0.1 ; * 0.01 \leq p<0.05$; $* * 0.001 \leq p<0.01 ; * * * p<0.001$

${ }^{\text {a }}$ Indicates that the estimated parameter is given for the quadratic term of this variable

content, the probability to detect the corresponding enzyme activities increased always together with them. In $P$. abies CWD, the probability to measure Lacc, GenP and MnP activities was negatively correlated with the content of extractives. In terms of $\mathrm{pH}$, there was no general type of response. It depended on the type of enzyme and the tree species, whether the logistic regression was positively linear or quadratic. Species richness contributed only to the final model of Lacc in F. sylvatica CWD, and the total lignin content did not contribute to any model.

\section{Correlations between enzyme activities, physico- chemical properties and species richness}

To analyze which parameters promote the activities of Lacc, GenP and MnP, the correlation analyses were performed only for samples with enzyme activities $\geq 1 \mathrm{mU} \mathrm{g}^{-1}$. All final models showed only low minor $r$ squares (Table 6). In particular, for $F$. sylvatica CWD, they were low, ranging from 0.09 to 0.11 . For coniferous CWD, the models were better with a minor $r$-square between 0.15 
Table 6 Selected final linear models of Lacc, GenP and MnP activities in dependence of physico-chemical parameters and fungal community parameters, modeled only with samples showing enzyme activity $\geq 1 \mathrm{mU} \mathrm{g}^{-1}$ of the corresponding enzyme

\begin{tabular}{|c|c|c|c|c|c|c|c|c|c|}
\hline & \multicolumn{3}{|c|}{ F. sylvatica } & \multicolumn{3}{|l|}{ P. abies } & \multicolumn{3}{|c|}{ P. sylvestris } \\
\hline & Lacc & GenP & $\mathrm{MnP}$ & Lacc & GenP & $\mathrm{MnP}$ & Lacc & GenP & $\mathrm{MnP}$ \\
\hline Intercept & $-0.2^{\mathrm{NS}}$ & $0.00^{\mathrm{NS}}$ & $-0.2^{\mathrm{NS}}$ & $0.00^{\mathrm{NS}}$ & $-0.09^{\mathrm{NS}}$ & $-0.01^{\mathrm{NS}}$ & $-0.04^{\mathrm{NS}}$ & $-0.02^{\mathrm{NS}}$ & $0.00^{\mathrm{NS}}$ \\
\hline $\mathrm{pH}$ & & $0.26 * * *$ & & $-0.27 * *$ & & & & & \\
\hline Total lignin & & & & & & $-0.45^{* * *}$ & & & \\
\hline Extractives & & & & & & $0.28 *$ & & & \\
\hline Water-soluble lignin fragments & $0.26 * * *$ & & $0.28 * * *$ & & & $0.23 *$ & & & $0.61 * *$ \\
\hline Water content & $0.15^{*}$ & & $-0.23^{* * *}$ & $0.23 *$ & $0.41 * *$ & & & $0.39 *$ & \\
\hline Species richness & & & & & $-0.23 *$ & & & & \\
\hline NMDS axis 1 & & $-0.16^{* *}$ & & $-0.33 * * *$ & $-0.38 * *$ & $-0.23 *$ & $-0.55 * * *$ & & \\
\hline NMDS axis 2 & & & & $-0.24 * *$ & & & & & \\
\hline Minor $r$-square & 0.11 & 0.09 & 0.09 & 0.27 & 0.19 & 0.39 & 0.34 & 0.15 & 0.38 \\
\hline
\end{tabular}

The estimated parameters and their significance of each variable, which is retained in the final model, are given together with the minor $R^{2}$ of the whole final model

Significance of the estimated parameters in the model is symbolized by: ${ }^{\text {NS }} p \geq 0.1 ; \quad+0.05 \leq p<0.1 ; * 0.01 \leq p<0.05$; $* * 0.001 \leq p<0.01 ; * * * p<0.001$

and 0.38. The most frequent variables with five contributions to the final models were the water content and the fungal community represented by two NMDS axes. In relation to the water content, most correlations of the enzyme activities were positive with the exception of MnP activities in $F$. sylvatica CWD, which were negatively correlated. The amount of water-soluble lignin fragments was the second most important variable showing a positive effect on the activity of detectable enzymes. The $\mathrm{pH}$ was less influential with two contributions to the models, and the contents of total lignin and extractives as well as the species richness were only part of one final model each.

\section{Discussion}

Dead wood degradation by saprotrophic wood-inhabiting fungi is a complex process. They are metabolizing and mineralizing cellulose, hemicellulose and lignin to different extent and with different strategies. To make the polysaccharides better accessible for their hydrolytic enzymes like endoglucanase, cellobiohydrolase, $\beta$-glucosidase, xylanase and mannanase, they have to overcome the lignin barrier. For this purpose, white rot fungi apply a set of oxidoreductases (peroxidases and laccase) (Hatakka and Hammel 2011; Schwarze 2007).

\section{Lacc, GenP and MnP activities are highly variable}

Lacc, GenP and MnP activities detected in the analyzed CWD samples were often one or two orders of magnitude lower than enzyme activities typically found in "optimized" solid-state laboratory cultures of individual fungi (Fackler et al. 2006; Hahn et al. 2013; Liers et al. 2011). In general, there seems to be a wide variation in enzymatic activities in dead wood. Similar low enzyme activities as in the majority of our samples (Table 3) were measured by Valaskova et al. (2009) in strongly decayed wood within the range from 0 to $0.68 \mathrm{mU} \mathrm{g}^{-1}$ for Lacc and from 0.33 to $1.30 \mathrm{mU} \mathrm{g}^{-1}$ for MnP. In contrast, values up to $390 \mathrm{mU} \mathrm{g}^{-1}$ for Lacc and $1620 \mathrm{mU} \mathrm{g}^{-1}$ for MnP were found close to fruiting bodies of the WRF Fomes fomentarius in F. sylvatica logs (Větrovský et al. 2010), which is in the same order of magnitude as our observed maximum values. The large percentage of samples with relatively low Lacc, GenP and MnP activities (Tables 2, 3) may be a result of the high spatial variability of these enzymes. Each drill core across the logs covered altering and irregular zones of active lignocellulose degradation and zones with low or lacking enzyme activities (Boddy et al. 1989; Větrovský et al. 2010). As the result, local hot spots of enzymatic activities may have been overlooked. However, the high number of samples (701) in our study allows a realistic insight into the distribution of relevant oxidoreductase activities in CWD.

Lacc, GenP and MnP activities in F. sylvatica (broadleaved tree) were found to be significantly higher than in the two coniferous species (Table 3). This may be caused by different fungal communities, since different fungi prefer different tree species with their different characteristics (Schwarze 2007). For example, the here-studied tree species differed significantly in extractives, total lignin and wood density (Table 4). The low activities of the enzymes in coniferous wood suggest that it is rather degraded by 
BRF than by WRF, which is in accordance with the fact that BRF preferably colonize coniferous wood (Ryvarden and Gilbertson 1993) and do not secrete peroxidases and scarcely Lacc (Hatakka and Hammel 2011). This assumption is further supported by the high number of coniferous wood samples $(\sim 25 \%)$ with total lignin contents higher than $40 \%$ compared to the low number of respective samples of $F$. sylvatica $(\sim 6 \%)$. Nevertheless, the low but distinct Lacc, GenP and MnP activities found show that WRF do also occur in coniferous wood as it was reported, for example, for $P$. abies CWD (Rajala et al. 2012). The high percentage of small water-soluble lignin fragments detected in $P$. abies and $P$. sylvestris samples, which are characteristic for WRF attack (Liers et al. 2011), substantiates this fact since BRF do not cause the release of lignin fragments (Hahn et al., 2013). The high overall activities of oxidative enzymes observed in $F$. sylvatica samples imply vice versa that the decay of this tree species is dominated by WRF.

The first and second axis of the NMDS ordination for the fungal community is frequently part of the final model, which indicates the distinct influence of differences in the fungal community on the enzymatic activities and the probability to detect Lacc, GenP and MnP activities as incipiently hypothesized (H2). This is in accordance with different degradation rates previously observed for different fungal species compositions (Fukami et al. 2010) in Nothofagus solandri wood disks and the report of fungal community composition as the best predictor of mass loss in older stumps of $Q$. robur (van der Wal et al. 2015). In contrast, species richness appears only significant in one linear and one logistic model (Tables 5, 6), which clearly indicates that species richness is a good proxy neither for the fungal community nor for related processes.

Although the fungal community is without doubt responsible for the detected oxidative enzyme activities, their contribution to the final models is not such strong as it might be expected and the explanatory power of the final models is rather weak (Tables 5, 6). On the one hand, this finding might be a result of the complexity of individual communities per sample, which cannot be sufficiently accessed by statistics due to the stochastic fungal colonization process (Dix and Webster 1994) and the multidimensional development of fungal communities with diverse optional pathways (Boddy 2001; Stokland et al. 2012). Recently, van der Wal et al. (2015) demonstrated that the fungal community in old $Q$. robur stumps is similar to a randomly assembled community. Moreover, the status of development of each fungus and the status of interaction between the fungi will be relevant, too, since: (1) each fungus accomplishes an individual set and temporal pattern of extracellular oxidoreductase activities (Liers et al. 2011), (2) these activities are higher when a fungus is capturing fresh unoccupied wood (Hahn et al. 2013; Větrovský et al. 2010), (3) during interaction of several fungal species, activities of Lacc or MnP can increase (Baldrian 2004; Hiscox et al. 2010; Šnajdr et al. 2011), and (4) competition between fungi can hamper wood degradation (Fukasawa et al. 2009b). This complex interplay of fungal species may be the reason for the observed extreme variability (Table 3) and cannot be explained by solely analyzing the fungal community. For a better understanding of the secretion of fungal laccase and peroxidases, the analysis of the functional fungal community by expression studies for each enzyme based on transcriptomics will be useful (Kellner et al. 2014).

Last but not least, the low explanatory power may also be an effect of timescales. Lacc, GenP and MnP activities describe the current decay process (activity "snapshot"), in a time frame of days (or weeks at best) depending on enzyme stability, while all other physico-chemical properties describe the results of the whole past decay process. This applies also to the fungal community data used here, which cover all species from the past decay process, since the OTUs are derived from total DNA that includes DNA of living but also of dead and/or inactive fungi (Purahong and Krüger 2012).

\section{Lacc, GenP and MnP activities are crucial for lignin conversion in CWD}

The measured oxidative activities (Lacc, GenP, MnP) are representative for the most important extracellular enzymes involved in the chemical modification and degradation of lignin (Hatakka and Hammel 2011). The considerable number of samples where we detected relevant activities (Table 2) indicates their general significance for CWD decay. As a result of delignification, we found, in the majority of samples, distinct patterns of water-soluble lignin fragments (Fig. 1), similar to those detectable in solid-state pure cultures in the laboratory (Liers et al. 2011). But vice versa these fragments can also influence the production/activity of enzymes (feedback regulation). Notably, we found water-soluble lignin fragments to be one of the most important variables to predict the activities of Lacc and MnP as well as the probability to detect them (Tables 5, 6). There were always positive correlations with enzyme activities and the probability to detect them. This indicates the strong relation of Lacc and MnP to the process of lignin degradation. Contrary to our initial assumption, with total lignin, there was no logistic regression for all measured enzyme activities and only one linear model, namely that for $\mathrm{MnP}$ activity in $P$. abies CWD. This may be an effect of different timescales, in which total lignin is the result of the whole past decay process, while water-soluble lignin fragments are rather the 
result of short-time activities and hence are more related to the actual decay process similar to the activity of enzymes. Despite the strong relations between water-soluble lignin fragments and activities of Lacc as well as $\mathrm{MnP}$, it is, for the time being, impossible to disentangle whether the enzymatic activities or the water-soluble lignin fragments are cause or effect.

According to the activities detected, Lacc was the most frequent enzyme in CWD (Table 2), which may be due to its involvement in different processes including fruiting body development, pigmentation of fungal spores, rhizomorph formation, detoxification reactions and sexual differentiation additional to lignin modification (Boddy 2000; Leonowicz et al. 2001). The fact that water-soluble lignin fragments were frequently part of the final models for Lacc in CWD (Tables 5, 6) is an indication for the contribution of Lacc to lignin modification, inasmuch as it facilitates the detoxification of phenolic wood ingredients and phenolic fragments formed by peroxidases, which on their part can affect fungal growth and peroxidase performance (Bollag et al. 1988; Leonowicz et al. 2001; Upadhyay and Hofrichter 1993). As a typical result of Lacc action, we found water-soluble lignin fragments with a predominant mass around $40 \mathrm{kDa}$, which is also characteristic for fungi secreting Lacc as sole extracellular oxidoreductase (e.g., Xylaria spp.; Liers et al. 2011). On the other hand, when looking at the molecular mass distribution as a whole, the $40-\mathrm{kDa}$ fraction contributes only to a minor extent to the total amount of soluble lignin fragments (Fig. 1), which rather points to a limited role of Lacc in the overall degradation process.

The frequency of MnP and GenP activities in the samples was similar (Table 2); however, only in the final models for $\mathrm{MnP}$, water-soluble lignin fragments were predictors and total lignin was it in the final model of $\mathrm{MnP}$ activity in $P$. abies. These relations to water-soluble lignin fragments and total lignin confirm the crucial role of $\mathrm{MnP}$ in lignin degradation, which was proposed after laboratory studies demonstrating the ability of $\mathrm{MnP}$ to depolymerize lignin and even to mineralize it to $\mathrm{CO}_{2}$ (Hofrichter et al. 1999; Kapich et al. 1999). In this context, it is also noteworthy to mention that $\mathrm{MnP}$ is the most frequent type of peroxidase secreted not only by wood-rot WRF but also by leaf-litter dwelling basidiomycetes (Hofrichter et al. 2010; Lundell et al. 2014). The significance of MnP for ligninolysis was further emphasized by the frequency of a characteristic fraction of water-soluble lignin fragments (with a molecular mass around $1 \mathrm{kDa}$ indicative for $\mathrm{MnP}$ attack) occurring in $70 \%$ of all samples (Fig. 1; Hofrichter et al. 2001). Even though enzymatic MnP activities were not always detectable, the presence of the enzyme can be inferred from these fragments that are far more stable than the peroxidase protein itself (Liers et al. 2011).
Although in the final model for GenP activities in CWD, water-soluble lignin fragments did not appear, this does not necessarily mean that the peroxidases behind these activities are not involved in the degradation of lignin. It must be considered that the GenP activities measured here represent sum activities that rely on several fungal peroxidases (Kellner et al. 2014), among which only LiP and VP are truly ligninolytic (Hofrichter et al. 2010; Ruiz-Dueñas and Martínez 2009). Consequently, the relation of LiP and VP to water-soluble lignin fragments could be masked/corrupted by activities of GP, UPO and DyP (Hofrichter et al. 2010; Liers et al. 2011). In future studies, the use of more specific peroxidase substrates (that will have to be selected carefully) in combination with proteomic approaches will help to distinguish the different enzymes hiding behind GenP activities.

\section{Optimum parameters for Lacc, GenP and MnP activities}

In this study, the $\mathrm{pH}$ and the presence of metals (copper, iron, manganese) were found to be important boundary conditions for the extracellular oxidoreductase activities and their magnitude was in the range of suitable conditions determined in numerous laboratory tests (Baldrian 2006; Brown et al. 1990; Hofrichter et al. 2010; Kirk and Cullen 1998; Levin et al. 2005).

In some cases, the $\mathrm{pH}$ was an important predictor for the enzyme activities and the probability to detect them in the final models (Tables 5, 6). Most samples showed an acidic $\mathrm{pH}$ (Table 4), which is similar to the acidic $\mathrm{pH}$ optima (3.0-5.5) of purified Lacc, LiP, VP or MnP (Baldrian 2006; Hofrichter et al. 2010; Kirk and Cullen 1998), which supports the hypothesis that an acidic $\mathrm{pH}$ facilitates extracellular oxidoreductase activities related to lignin modification. Most contributions of $\mathrm{pH}$ to the final models (Tables 5,6) were found for coniferous CWD. This could be the result of a stronger acidification by BRF that prefer this type of wood (Ryvarden and Gilbertson 1993) and secrete oxalic acid over their whole life cycle in contrast to WRF (Dutton et al. 1993; Shimada et al. 1997). Since the observed interquartile range of $\mathrm{pH}$ was quite small (Table 4), it is hard to interpret the different increasing, decreasing or quadratic functions of $\mathrm{pH}$ and the corresponding enzyme activity. This finding merely underlines the importance of $\mathrm{pH}$ for the functioning of extracellular oxidoreductases.

For essential heavy metals $(\mathrm{Mn}, \mathrm{Fe}, \mathrm{Cu})$, it is not possible to disentangle their individual influence on the Lacc, GenP and MnP activities in CWD, since they were strongly correlated with each other and with water-soluble lignin fragments $(R=0.48-0.77$; Online Resource: Table S4S6). However, the univariate consideration before fitting 
the multivariate models revealed some positive effects of these metals on Lacc, GenP and MnP activities (Online Resource: Table S9 \& S10), as hypothesized in the beginning (H1). It is well known from laboratory studies that minimal levels of these metals are indispensable for the synthesis and functioning of extracellular oxidoreductases (Baldrian 2006; Brown et al. 1990; Hofrichter et al. 2010; Levin et al. 2005).

The majority of manganese concentrations detected in the aqueous phase of wood samples (Online Resource: Table S8) were in the range (or higher) of the $K_{\mathrm{m}}$ values (Michaelis-Menten constants) of MnP for $\mathrm{Mn}^{2+}$. Collected $K_{\mathrm{m}}$ data from the literature were used to calculate a mean value of $26 \mu \mathrm{M} \mathrm{Mn}^{2+}$ within a range from 4 to $124 \mu \mathrm{M}$ $(n=26)$ (Online Resource: Table S11). Interestingly, between 25 and $75 \%$ of the samples contained bioavailable manganese in concentrations that are usually used to assay MnP activities (100-500 $\mu \mathrm{M})($ Camarero et al. 1996; Fackler et al. 2006; Hofrichter et al. 1999). This strongly indicates that the natural concentration of bioavailable manganese in wood is sufficient to guarantee the functioning of $\mathrm{MnP}$ (that uses $\mathrm{Mn}^{3+}$ as actual oxidant) and thereby enables incipient lignin oxidation (Hofrichter 2002). The concentrations of copper in the aqueous phase of wood samples were five to six orders of magnitude lower than concentrations known to be toxic to fungi (Sanglimsuwan et al. 1993) and two orders of magnitude lower than the concentrations used to induce Lacc production in liquid laboratory cultures (Levin et al. 2005; Tavares et al. 2005). But it is noteworthy that there are remarkable differences between fungal species in the way they tolerate and respond to variant concentrations of copper ions (Baldrian 2003; Mäkelä et al. 2013). Furthermore, also the activity of $\mathrm{MnP}$ can be enhanced in the presence of copper as observed for Trametes trogii (Levin et al. 2005). Nevertheless, the copper concentrations (interquartile range 3-7 $\mu \mathrm{M}$; Online Resource: Table S8)and also the iron levels (interquartile range 13-53 $\mu \mathrm{M}$; Online Resource: Table S8) - in wood were found to be sufficient for fungal growth and functioning of their enzymes. Copper and iron regulate the cellular metabolism and gene expression, and are also needed as cofactors in multiple core metabolic enzymes, receptors and trafficking of structural proteins (Baldrian 2003; Huffman and O’Halloran 2001; Lundell et al. 2014; Philpott 2006).

\section{Water content is an important determinant of extracellular oxidoreductase activities}

Density and water content of dead wood is permanently changing with the ongoing decay process. Thus, wood density decreases, and as a result, the water content increases, indicated by their strong negative correlation. The univariate consideration before fitting the multivariate models revealed that there are more significant univariate correlations and logistic regression with the tested enzymes for the water content than for wood density. The effect of density may be superposed by that of the water content. Wood density slowly decreases during the decay process, and in contrast, the water content is subject to fluctuations caused by precipitation or drought, which in turn will lead to responses by the fungi (Chambers et al. 2001). Different fungal species can also shape the water content during degradation to different extent (Boddy et al. 1989; Fukasawa et al. 2005). Therefore, only the water content was added to the maximal model for multivariate modeling.

The model selection demonstrated that the water content-as expected-is an important determining factor for activities of Lacc, GenP and MnP as well as for the probability to detect them in CWD (Tables 5,6 ). This fits well to observations made for respiration rates as proxy for the fungal degradation activity, which is partly the result of lignin mineralization (Hagemann et al. 2010; Herrmann and Bauhus 2013; Hofrichter et al. 1999). In most cases, where the water content was retained in the final model, the activities of the corresponding enzymes and the probability to detect them increased with the water content. Only the activity of $\mathrm{MnP}$ in $F$. sylvatica $\mathrm{CWD}$ decreased with increasing water content. This may indicate that $\mathrm{MnP}$ is most important in the beginning of the decay process in $F$. sylvatica CWD, as the water content increased with ongoing decay. However, for respiration rates, both directions of response have been reported (Boddy 1983; Liu et al. 2006; Progar et al. 2000).

\section{Conclusions}

By analyzing $701 \mathrm{CDW}$ samples of $F$. sylvatica, $P$. abies and $P$. sylvestris across three regions in Germany, we frequently found activities of extracellular oxidoreductases, i.e., laccase (Lacc), manganese peroxidase $(\mathrm{MnP})$ and several other peroxidases [subsumed under general peroxidase (GenP) and also referred to as manganese-independent peroxidases (Morais et al. 2002)], which highlights their importance for the chemical modification and decomposition of lignin and hence for carbon cycling in forests. In particular, manganese-oxidizing peroxidases dominate the disintegration of lignin, which is supported by the observed patterns of water-soluble lignin fragments formed during wood decay and by the correlation and logistic regressions of water-soluble lignin fragments and MnP.

Lacc, GenP and MnP show complex and highly variable patterns in their activities, which are controlled by an 
array of factors including tree species, water content, water-soluble lignin fragments, $\mathrm{pH}$ and availability of manganese, copper and iron. As initially hypothesized, the fungal community structure was the most important determinant that influences the presence and activities of these enzymes. But low explanatory power of all final models indicates that the community structure and the important physico-chemical variables are not sufficient to explain the complexity of extracellular oxidoreductase patterns in CWD. The individual development of each fungus, the fungal identity and abundance as well as the status of interaction between the fungi may be more important. For a better explanation of fungal laccase and peroxidase occurrence in the future, functional analysis of the fungal community by RNA-based expression studies for individual enzyme will be necessary along with enzymatic and molecular analyses of (hemi)cellulytic hydrolases.

Acknowledgments We thank the managers of the three Exploratories, Kirsten Reichel-Jung, Swen Renner, Katrin Hartwich, Sonja Gockel, Kerstin Wiesner and Martin Gorke for their work in maintaining the plot and project infrastructure, Christiane Fischer and Simone Pfeiffer for giving support through the central office, Michael Owonibi for managing the central data base, and Markus Fischer, Eduard Linsenmair, Dominik Hessenmöller, Jens Nieschulze, Daniel Prati, Ingo Schöning, François Buscot, Ernst-Detlef Schulze, Wolfgang W. Weisser and the late Elisabeth Kalko for their role in setting up the Biodiversity Exploratories project and our coworkers in the laboratory Constanze Stark, Heike Heidenreich, Andreas Elsner and all student helpers for technical assistance. Thanks also to René Ullrich for all advices and support. Field work permits were issued by the responsible state environmental offices of Baden-Württemberg, Thüringen, and Brandenburg (according to $\S 72 \mathrm{BbgNatSchG).}$

Funding The work has been funded by the Deutsche Forschungsgemeinschaft (DFG) within the Priority Program 1374 on "Infrastructure-Biodiversity-Exploratories" (BU941/17-1, KR3587/3-2, BA 2821/9-1, BA 2821/9-2, HO 1961/5-1, HO 1961/5-2, www.DFG.de).

\section{Compliance with ethical standards}

This material is original research, has not been previously published and has not been submitted for publication elsewhere while under consideration. Hereby I confirm that the submission of the manuscript has been approved by all of the authors and the International Institute Zittau (TU Dresden) as institution where the majority of work was carried out. I certify on behalf of all coauthors that there is neither a financial nor a non-financial conflict of interest.

Conflict of interest The authors declare that they have no conflict of interest.

Open Access This article is distributed under the terms of the Creative Commons Attribution 4.0 International License (http://crea tivecommons.org/licenses/by/4.0/), which permits unrestricted use, distribution, and reproduction in any medium, provided you give appropriate credit to the original author(s) and the source, provide a link to the Creative Commons license, and indicate if changes were made.

\section{References}

Baldrian P (2003) Interactions of heavy metals with white-rot fungi. Enzyme Microb Technol 32:78-91. doi:10.1016/S0141-0229 (02)00245-4

Baldrian P (2004) Increase of laccase activity during interspecific interactions of white-rot fungi. FEMS Microbiol Ecol 50:245-253. doi:10.1016/j.femsec.2004.07.005

Baldrian P (2006) Fungal laccases-occurrence and properties. FEMS Microbiol Rev 30:215-242. doi:10.1111/j.1574-4976.2005. 00010.x

Bartoń K (2015) Multi-model inference R package version 1.13.4

Bates D, Maechler M, Bolker B, Walker S (2014) Linear mixedeffects models using Eigen and S4. R package version 1.0-6 https://cran.r-project.org/web/packages/lme4/index.html

Boddy L (1983) Carbon dioxide release from decomposing wood: effect of water content and temperature. Soil Biol Biochem 15:501-510. doi:10.1016/0038-0717(83)90042-1

Boddy L (2000) Interspecific combative interactions between wooddecaying basidiomycetes. FEMS Microbiol Ecol 31:185-194. doi:10.1111/j.1574-6941.2000.tb00683.x

Boddy L (2001) Fungal community ecology and wood decomposition processes in angiosperms: from standing tree to complete decay of coarse woody debris. In: Jonsson BG, Kruys N (eds) Ecology of woody debris in boreal forests, vol 49. Ecological Bulletins. Wiley-Blackwell, London, pp 43-56

Boddy L, Owens EM, Chapela IH (1989) Small scale variation in decay rate within logs one year after felling: effect of fungal community structure and moisture content. FEMS Microbiol Lett 62:173-183. doi:10.1111/j.1574-6968.1989.tb03691.x

Bollag JM, Shuttleworth KL, Anderson DH (1988) Laccase-mediated detoxification of phenolic compounds. Appl Environ Microbiol 54:3086-3091

Brown JA, Glenn JK, Gold MH (1990) Manganese regulates expression of manganese peroxidase by Phanerochaete chrysosporium. J Bacteriol 172:3125-3130

Camarero S, Bockle B, Martinez MJ, Martinez AT (1996) Manganese-mediated lignin degradation by Pleurotus pulmonarius. Appl Environ Microbiol 62:1070-1072

Chambers JQ, Schimel JP, Nobre AD (2001) Respiration from coarse wood litter in central Amazon forests. Biogeochemistry 52:115-131. doi:10.1023/a:1006473530673

Crawley MJ (2012) Binary response variables. In: The R book. Wiley, pp 650-665. doi:10.1002/9781118448908.ch17

Dence CW (1992) The determination of lignin. In: Lin SY, Dence $\mathrm{CW}$ (eds) Methods in lignin chemistry. Springer, Berlin, pp 33-61

Dix NJ, Webster J (1994) Fungal ecology. Springer-Science + Business Media B.V., Wallington

Dixon RK, Solomon AM, Brown S, Houghton RA, Trexier MC, Wisniewski J (1994) Carbon pools and flux of global forest ecosystems. Science 263:185-190. doi:10.1126/science.263. 5144.185

Doyle JJ, Doyle JL (1987) A rapid DNA isolation procedure for small quantities of fresh leaf tissue. Phytochem Bull 19:11-15

Dutton MV, Evans CS, Atkey PT, Wood DA (1993) Oxalate production by Basidiomycetes, including the white-rot species Coriolus versicolor and Phanerochaete chrysosporium. Appl Microbiol Biotechnol 39:5-10. doi:10.1007/bf00166839

Effland MJ (1977) Modified procedure to determine acid-insoluble lignin in wood and pulp. Tappi 60:143-144

Fackler K, Gradinger C, Hinterstoisser B, Messner K, Schwanninger M (2006) Lignin degradation by white rot fungi on spruce wood shavings during short-time solid-state fermentations monitored 
by near infrared spectroscopy. Enzyme Microb Technol 39:1476-1483. doi:10.1016/j.enzmictec.2006.03.043

FAO (2010) Global forest resources assessment 2010 main report. Food and Agriculture Organization of the United Nations, Rome

Fengel D, Wegener G (2003) Wood: chemistry, ultrastructure, reactions. Kessel Verlag, Remagen

Fischer M et al (2010) Implementing large-scale and long-term functional biodiversity research: the biodiversity exploratories. Basic Appl Ecol 11:473-485. doi:10.1016/j.baae.2010. 07.009

Fukami T et al (2010) Assembly history dictates ecosystem functioning: evidence from wood decomposer communities. Ecol Lett 13:675-684. doi:10.1111/j.1461-0248.2010.01465.x

Fukasawa Y, Osono T, Takeda H (2005) Small-scale variation in chemical property within logs of Japanese beech in relation to spatial distribution and decay ability of fungi. Mycoscience 46:209-214. doi:10.1007/s10267-005-0236-x

Fukasawa Y, Osono T, Takeda H (2009a) Dynamics of physicochemical properties and occurrence of fungal fruit bodies during decomposition of coarse woody debris of Fagus crenata. J For Res 14:20-29. doi:10.1007/s10310-008-0098-0

Fukasawa Y, Osono T, Takeda H (2009b) Effects of attack of saprobic fungi on twig litter decomposition by endophytic fungi. Ecol Res 24:1067-1073. doi:10.1007/s11284-009-0582-9

Gardes M, Bruns TD (1993) ITS primers with enhanced specificity for basidiomycetes - application to the identification of mycorrhizae and rusts. Mol Ecol 2:113-118. doi:10.1111/j.1365-294X. 1993.tb00005.x

Hagemann U, Moroni MT, Gleißner J, Makeschin F (2010) Disturbance history influences downed woody debris and soil respiration. For Ecol Manag 260:1762-1772. doi:10.1016/j.foreco. 2010.08.018

Hahn F, Ullrich R, Hofrichter M, Liers C (2013) Experimental approach to follow the spatiotemporal wood degradation in fungal microcosms. Biotechnol J 8:127-132. doi:10.1002/biot. 201200183

Hatakka A, Hammel KE (2011) Fungal biodegradation of lignocelluloses. In: Hofrichter M (ed) Industrial applications, vol 10. The Mycota. Springer, Berlin, pp 319-340. doi:10.1007/978-3-64211458-8_15

Herrmann S, Bauhus J (2013) Effects of moisture, temperature and decomposition stage on respirational carbon loss from coarse woody debris (CWD) of important European tree species. Scand J For Res 28:346-357. doi:10.1080/02827581.2012.747622

Hessenmöller D, Nieschulze J, Seele C, von Lüpke N, Schulze E-D (2011) Identification of forest management types from groundbased and remotely sensed variables and the effects of forest. Forstarchiv 82:171-183. doi:10.4432/03004112-82-171

Hiscox J, Baldrian P, Rogers HJ, Boddy L (2010) Changes in oxidative enzyme activity during interspecific mycelial interactions involving the white-rot fungus Trametes versicolor. Fungal Genet Biol 47:562-571. doi:10.1016/j.fgb.2010.03.007

Hofrichter M (2002) Review: lignin conversion by manganese peroxidase (MnP). Enzyme Microb Technol 30:454-466. doi:10.1016/S0141-0229(01)00528-2

Hofrichter M, Ullrich R (2014) Oxidations catalyzed by fungal peroxygenases. Curr Opin Chem Biol 19:116-125. doi:10.1016/ j.cbpa.2014.01.015

Hofrichter M, Vares T, Kalsi M, Galkin S, Scheibner K, Fritsche W, Hatakka A (1999) Production of manganese peroxidase and organic acids and mineralization of ${ }^{14} \mathrm{C}$-labelled lignin $\left({ }^{14} \mathrm{C}\right.$ DHP) during solid-state fermentation of wheat straw with the white rot fungus Nematoloma frowardii. Appl Environ Microbiol 65:1864-1870

Hofrichter M, Lundell T, Hatakka A (2001) Conversion of milled pine wood by manganese peroxidase from Phlebia radiata. Appl
Environ Microbiol 67:4588-4593. doi:10.1128/AEM.67.10. 4588-4593.2001

Hofrichter M, Ullrich R, Pecyna MJ, Liers C, Lundell T (2010) New and classic families of secreted fungal heme peroxidases. Appl Microbiol Biotechnol 87:871-897. doi:10.1007/s00253-0102633-0

Hoppe B, Kahl T, Karasch P, Wubet T, Bauhus J, Buscot F, Krüger D (2014) Network analysis reveals ecological links between $\mathrm{N}$-fixing bacteria and wood-decaying fungi. PLoS ONE 9:e88141. doi:10.1371/journal.pone.0088141

Huffman DL, O'Halloran TV (2001) Function, structure, and mechanism of intracellular copper trafficking proteins. Annu Rev Biochem 70:677-701. doi:10.1146/annurev.biochem.70.1.677

Kapich A, Hofrichter M, Vares T, Hatakka A (1999) Coupling of manganese peroxidase-mediated lipid peroxidation with destruction of nonphenolic lignin model compounds and ${ }^{14} \mathrm{C}$-labeled lignins. Biochem Biophys Res Commun 259:212-219. doi:10. 1006/bbrc. 1999.0742

Kellner $\mathrm{H}$ et al (2014) Widespread occurrence of expressed fungal secretory peroxidases in forest soils. PLoS ONE 9:e95557. doi:10.1371/journal.pone.0095557

Kirk T (1984) Degradation of lignin. In: Gibson DT (ed) Microbial degradation of organic compounds, vol 13. Microbiology series. Marcel Dekker, New York, pp 399-437

Kirk TK, Cullen D (1998) Enzymology and molecular genetics of wood degradation by white-rot fungi. In: Young RA, Akhtar M (eds) Environmentally friendly technologies for the pulp and paper industry. Wiley, New York, pp 273-307

Kjalke M, Andersen MB, Schneider P, Christensen B, Schülein M, Welinder KG (1992) Comparison of structure and activities of peroxidases from Coprinus cinereus, Coprinus macrorhizus and Arthromyces ramosus. Biochim Biophys Acta 1120:248-256. doi:10.1016/0167-4838(92)90244-8

Lackner R, Srebotnik E, Messner K (1991) Oxidative degradation of high molecular weight chlorolignin by manganese peroxidase of Phanerochaete chrysosporium. Biochem Biophys Res Commun 178:1092-1098. doi:10.1016/0006-291X(91)91004-V

Lefcheck J (2014) $\mathrm{R}^{2}$ for linear mixed effects models. http:// jonlefcheck.net/2013/03/13/r2-for-linear-mixed-effects-models/. Accessed 6 October 2014

Leonowicz A et al (2001) Fungal laccase: properties and activity on lignin. J Basic Microbiol 41:185-227. doi:10.1002/15214028(200107)41:3/4<185:AID-JOBM185>3.0.CO;2-T

Levin L, Forchiassin F, Viale A (2005) Ligninolytic enzyme production and dye decolorization by Trametes trogii: application of the Plackett-Burman experimental design to evaluate nutritional requirements. Process Biochem 40:1381-1387. doi:10.1016/j.procbio.2004.06.005

Liers C, Ullrich R, Steffen KT, Hatakka A, Hofrichter M (2006) Mineralization of ${ }^{14} \mathrm{C}$-labelled synthetic lignin and extracellular enzyme activities of the wood-colonizing ascomycetes Xylaria hypoxylon and Xylaria polymorpha. Appl Microbiol Biotechnol 69:573-579. doi:10.1007/s00253-005-0010-1

Liers C, Arnstadt T, Ullrich R, Hofrichter M (2011) Patterns of lignin degradation and oxidative enzyme secretion by different woodand litter-colonizing basidiomycetes and ascomycetes grown on beech-wood. FEMS Microbiol Ecol 78:91-102. doi:10.1111/j. 1574-6941.2011.01144.x

Liu W, Bryant D, Hutyra L, Saleska S, Hammond-Pyle E, Curran D, Wofsy S (2006) Woody debris contribution to the carbon budget of selectively logged and maturing mid-latitude forests. Oecologia 148:108-117. doi:10.1007/s00442-006-0356-9

Lundell TK, Mäkelä MR, Hildén K (2010) Lignin-modifying enzymes in filamentous basidiomycetes-ecological, functional and phylogenetic review. J Basic Microbiol 50:5-20. doi:10. 1002/jobm.200900338 
Lundell TK, Mäkelä MR, de Vries RP, Hildén KS (2014) Chapter eleven-genomics, lifestyles and future prospects of wooddecay and litter-decomposing basidiomycota. In: Francis MM (ed) Advances in botanical research, vol 70. Academic Press, London, pp 329-370. doi:10.1016/B978-0-12-397940-7.00011-2

Luyssaert S, Hessenmöller D, von Lüpke N, Kaiser S, Schulze ED (2011) Quantifying land use and disturbance intensity in forestry, based on the self-thinning relationship. Ecol Appl 21:3272-3284. doi:10.1890/10-2395.1

Mäkelä MR, Lundell T, Hatakka A, Hildén K (2013) Effect of copper, nutrient nitrogen, and wood-supplement on the production of lignin-modifying enzymes by the white-rot fungus Phlebia radiata. Fungal Biol 117:62-70. doi:10.1016/j.funbio.2012.11. 006

Morais H, Ramos C, Forgács E, Cserháti T, Oliviera J (2002) Using spectrophotometry and spectral mapping technique for the study of the production of manganese-dependent and manganeseindependent peroxidases by Pleurotus ostreatus. J Biochem Biophys Methods 50:99-109. doi:10.1016/S0165-022X(01) 00169-5

Nakagawa S, Schielzeth H (2013) A general and simple method for obtaining R2 from generalized linear mixed-effects models. Methods Ecol Evol 4:133-142. doi:10.1111/j.2041-210x.2012. 00261.x

Oksanen $\mathbf{J}$ et al (2013) vegan: community ecology package. R package version 2.0-10 https://cran.r-project.org/package=vegan

Philpott CC (2006) Iron uptake in fungi: a system for every source. Biochim Biophys Acta 1763:636-645. doi:10.1016/j.bbamcr. 2006.05.008

Pinheiro J, Bates D, DebRoy S, Sarkar D, R Core Team (2013) nlme: linear and nonlinear mixed effects models. $\mathrm{R}$ package version 3.1-113

Progar RA, Schowalter TD, Freitag CM, Morrell JJ (2000) Respiration from coarse woody debris as affected by moisture and saprotroph functional diversity in Western Oregon. Oecologia 124:426-431. doi:10.1007/pl00008868

Purahong W, Krüger D (2012) A better understanding of functional roles of fungi in the decomposition process: using precursor rRNA containing ITS regions as a marker for the active fungal community. Ann For Sci 69:659-662. doi:10.1007/s13595-0120210-7

Purahong W et al (2014) Changes within a single land-use category alter microbial diversity and community structure: molecular evidence from wood-inhabiting fungi in forest ecosystems. J Environ Manag 139:109-119. doi:10.1016/j.jenvman.2014.02. 031

R Core Team (2014) R: a language and environment for statistical computing. R Foundation for Statistical Computing. http://www. R-project.org/

Rajala T, Peltoniemi M, Pennanen T, Mäkipää R (2012) Fungal community dynamics in relation to substrate quality of decaying Norway spruce (Picea abies [L.] Karst.) logs in boreal forests. FEMS Microbiol Ecol 81:494-505. doi:10.1111/j.1574-6941. 2012.01376.x

Ramette A (2009) Quantitative community fingerprinting methods for estimating the abundance of operational taxonomic units in natural microbial communities. Appl Environ Microbiol 75:2495-2505. doi:10.1128/aem.02409-08
Ranjard L, Poly F, Lata J-C, Mougel C, Thioulouse J, Nazaret S (2001) Characterization of bacterial and fungal soil communities by automated ribosomal intergenic spacer analysis fingerprints: biological and methodological variability. Appl Environ Microbiol 67:4479-4487. doi:10.1128/aem.67.10.4479-4487.2001

Ruiz-Dueñas FJ, Martínez ÁT (2009) Microbial degradation of lignin: how a bulky recalcitrant polymer is efficiently recycled in nature and how we can take advantage of this. Microb Biotechnol 2:164-177. doi:10.1111/j.1751-7915.2008.00078.x

Ryvarden L, Gilbertson RL (1993) European polypores Part 1. Fungiflora. Lubrecht \& Cramer, Oslo

Sanglimsuwan S, Yoshida N, Morinaga T, Murooka Y (1993) Resistance to and uptake of heavy metals in mushrooms. J Ferment Bioeng 75:112-114. doi:10.1016/0922-338X(93) 90220-3

Schwarze FWMR (2007) Wood decay under the microscope. Fungal Biol Rev 21:133-170. doi:10.1016/j.fbr.2007.09.001

Shimada M, Akamtsu Y, Tokimatsu T, Mii K, Hattori T (1997) Possible biochemical roles of oxalic acid as a low molecular weight compound involved in brown-rot and white-rot wood decays. J Biotechnol 53:103-113. doi:10.1016/S0168-1656(97) 01679-9

Šnajdr J, Dobiášová P, Větrovský T, Valášková V, Alawi A, Boddy L, Baldrian P (2011) Saprotrophic basidiomycete mycelia and their interspecific interactions affect the spatial distribution of extracellular enzymes in soil. FEMS Microbiol Ecol 78:80-90. doi:10.1111/j.1574-6941.2011.01123.x

Soares CL, Duran N (2001) Biodegradation of chlorolignin and lignin-like compounds contained in $\mathrm{E}_{1}$-pulp bleaching effluent by fungal treatment. Appl Biochem Biotechnol 95:135-149. doi:10.1385/ABAB:95:2:135

Stokland JN, Siitonen J, Jonsson BG (2012) Biodiversity in dead wood. Cambridge University Press, New York

Tavares APM, Coelho MAZ, Coutinho JAP, Xavier A (2005) Laccase improvement in submerged cultivation: induced production and kinetic modelling. J Chem Technol Biotechnol 80:669-676. doi:10.1002/jctb.1246

Upadhyay RC, Hofrichter M (1993) Effect of phenol on the mycelial growth and fructification in some of basidiomycetous fungi. J Basic Microbiol 33:343-347. doi:10.1002/jobm.3620330512

Valaskova V, de Boer W, Klein Gunnewiek PJA, Pospisek M, Baldrian P (2009) Phylogenetic composition and properties of bacteria coexisting with the fungus Hypholoma fasciculare in decaying wood. ISME J 3:1218-1221. doi:10.1038/ismej.2009.64

van der Wal A, Ottosson E, de Boer W (2015) Neglected role of fungal community composition in explaining variation in wood decay rates. Ecology 96:124-133. doi:10.1890/14-0242.1

Větrovský T, Voříšková J, Šnajdr J, Gabriel J, Baldrian P (2010) Ecology of coarse wood decomposition by the saprotrophic fungus Fomes fomentarius. Biodegradation 22:709-718. doi:10. 1007/s10532-010-9390-8

Weedon JT, Cornwell WK, Cornelissen JH, Zanne AE, Wirth C, Coomes DA (2009) Global meta-analysis of wood decomposition rates: A role for trait variation among tree species? Ecol Lett $12: 45-56$

White TJ, Bruns T, Lee S, Taylor J (1990) Amplification and direct sequencing of fungal ribosomal RNA genes for phylogenetics. PCR Protoc Guide Methods Appl 18:315-322 